\title{
1. Performance and the political subject in Richard II
}

Melissa Caldwell

\section{INTRODUCTION: THE AUDIENCE AS POLITICAL SUBJECT}

For its unflinching examination of the dangers of incompetent and weak political leadership, Richard II is among the most politically resonant of all of William Shakespeare's plays for a twenty-first-century audience. At first glance, its medieval setting and formal versification style might suggest that Shakespeare's intent was to work within the inflexible outcomes of morality plays or the de casibus tradition, which invariably trace the undoing of a leader back to their moral weakness. However, Shakespeare takes this historical tragedy in a different direction, as what is at issue in this play is not a leader's moral strength, but rather his skill and ability to perform as a leader. Dramatizing a monarch who lacks the expertise, maturity, and decision-making abilities of England's more accomplished kings, Shakespeare places the audience in the difficult position of having to decide how intolerable Richard really is as a king and to imagine what, if anything, they could do if such a monarch were to rule on England's throne again. The audience's position in this play is all the more striking since Richard II is unquestionably an anointed king with an uncontested claim to the throne. ${ }^{1}$ Henry Bolingbroke, Richard's cousin, and ultimately his rival, emerges as one possible, though imperfect, response to Richard's weak political leadership.

Through both Richard II and Bolingbroke, Shakespeare makes clear that a crucial component of leadership is performance itself, as both characters use political performance as a means to shore up their power. From the first to the last scenes of the play, Shakespeare draws our attention to their political performances in a way that demands judgment. As Shakespeare takes up the task of dramatizing the individual motivations of both Richard II and Bolingbroke, their performativity becomes the evidence upon which the audience must evaluate their success as political leaders. Nevertheless, the play stubbornly resists providing comforting conclusions to the audience about either of these charac- 
ters. As Charles R. Forker writes in his introduction to the Arden Shakespeare edition, "Depending on one's perspective ... Richard is either a tyrant or a martyr, Bolingbroke either a patriot or a ruthless opportunist." 2 The words and actions of both Richard and Bolingbroke seem to make a case for their versions of leadership, yet Shakespeare never fully validates either character's claims. Hence, the play stages an unresolved clash between the prerogatives of absolute rule and the reality of human fallibility, for Richard II is invested in the idea of sacred kingship even as it grapples with the consequences of that investment.

Written during the mid-1590s not long after England's defeat of the Spanish Armada, Richard II is the first installment of Shakespeare's second tetralogy that includes the two plays dramatizing the reign of Henry IV and culminates in the triumphant rise of the great English king Henry V. The play narrowly focuses on the end of the historic Richard II's reign, centering on the deposition of the king by his rebel cousin, the aristocrat Henry Bolingbroke. Although Richard banishes Bolingbroke from England early in the play, Bolingbroke quickly returns to England after his father dies and the king attempts to steal his lands. Having both popular support and that of a number of the English aristocracy, Bolingbroke ascends the throne when Richard abdicates his power. The play stages a dialectic between conformity to the status quo and radical reform that takes the form of treason and rebellion, but it is hardly clear-cut in endorsing either response as the correct one for a citizen to take. ${ }^{3}$ Like many of Shakespeare's other plays written during the late sixteenth century, it is difficult to read Richard II without considering how it reflects on Queen Elizabeth and the looming uncertainty of the succession crisis. With an aging monarch on the throne and the next monarch still in question, the play unearths England's anxieties about monarchy at a pivotal point in English history. ${ }^{4}$ While the tetralogy as a whole can be read as political propaganda in support of Elizabeth, taken alone Richard II is a much edgier play. During the reign of Elizabeth $I$, the first three quartos were printed only in censored format without Richard's deposition scene..$^{5}$ In the 1640s, the play must also chillingly have suggested a precedent for the deposition of Charles I, who identified with Richard. ${ }^{6}$ Seeking to distance himself from deposed monarchs altogether, Charles II banned the play during the Restoration. This pattern of censorship suggests the degree to which the play made England's monarchs nervous about its potential message about civic activism and monarchical reform.

Shakespeare's portrait of Richard emphasizes the monarch's lack of leadership in a way that makes Richard's performativity an index of his weakness. It also illustrates what happens when a monarch is profoundly indifferent to his audience's judgment. As Kristin Bezio argues, Richard has very little respect for his subjects, "believing them unworthy and himself above the need for performative negotiation." Richard can be so cavalier toward his political 
subjects because he believes his power is divinely sanctioned and therefore absolute. "Not all the water in the rough rude sea," Richard confidently affirms, "can wash the balm from an anointed king. / The breath of worldly men cannot depose / The deputy elected by the Lord" (3.2.50-3). ${ }^{8}$ The fact that the play reveals his arrogance and his error calls in question both his leadership abilities and the theory of divinely sanctioned monarchy. As a political counterpoint, Bolingbroke does not operate from such a presumption of power, and consequently, he never loses sight of his audience. The role Bolingbroke plays as a legitimate alternative to the monarch shows Shakespeare staging not just resistance to leadership, but resistance as leadership. But if Bolingbroke's performance is a more effective leadership strategy, it is not a more earnest or a morally superior one. ${ }^{9}$

While it is difficult not to read Richard II in light of the larger historic-tragic narrative of Shakespeare's tetralogy, considering Richard II and Bolingbroke solely within the world that Shakespeare creates for them is the most instructive approach to interpreting the play in a twenty-first-century context. ${ }^{10}$ If we read this play simply as the prologue to a narrative that will lead to Henry V's successful career as a monarch who seamlessly reunites legitimacy and political performance, then it is more difficult to recognize the critical perspectives on leadership that Shakespeare explores here. If instead we assess these political opponents on their own merits as leaders within the context of this work, the complexity of Shakespeare's attitudes toward political leadership and performance becomes more apparent. This framing in a sense replicates the imperfect process by which we formulate our own political judgments in the twenty-first century, which necessarily are made with the uncertainty of partial knowledge. ${ }^{11}$

At the same time that the play asks us to choose between Richard and Bolingbroke, it also offers a highly skeptical view of political leadership altogether. Recognizing the way that this play breaks ranks with the sixteenth-century trend of dramatists casting the usurper as the unequivocally evil tyrant, Doyeeta Majumder argues, "In the figure of Bolingbroke Shakespeare presents to us the new prince par excellence, a man who astutely understands the pulse of the nation as well as the shifting political discourses around him." ${ }^{\prime 2}$ Yet even if Bolingbroke is a more skilled performer, the play does not readily allow for such a reading. Richard II presents both Bolingbroke and Richard as viable and less-than-ideal candidates for the throne, while placing the theatrical audience in the seat of political judgment. Political pamphleteers at the turn of the century read Richard's deposition as "a kind of test case confirming or denying the rights of subjects to judge their rulers." 13 As Louise Cowan argues, the play does not question "whether the king can do no wrong"; rather, it asks the audience to consider "what to do with a monarch who has committed serious and habitual offenses." ${ }^{14}$ Shakespeare 
is not shy about documenting Richard's offenses: he replaces common law with kingly prerogative; seizes Bolingbroke's land; assassinates his political enemies; taxes his people excessively and without legitimate purpose; and disregards wise counsel, preferring the opinion of flatterers. Yet even with all these flaws, he is more a foolish than an evil king. But the reform of Richard and his court is complicated by the way in which Richard's performativity creates a culture of performance among his subjects. This is especially true for Bolingbroke, whose leadership at times seems more reactive than proactive, as he finds himself in the position of playing a role the king has created for him. If Bolingbroke is offered as a solution to the problem of Richard, his political actions are difficult to separate from Richard's political performance, for he struggles to fully extricate himself from Richard's performative tendencies to establish his own identity as a leader.

Taken on its own, Richard II offers many parallels to the American political landscape today, not the least of which are the expectations placed on individuals who hold the office of the president, the role of citizens in political reform, and the dangers of performative politics. The Trump White House was frequently compared to a reality television show, a genre that at once purports to be real even as the notion of reality itself gets turned into a performance. Indeed, while President Donald Trump seemed to largely elide what it means to be presidential, performativity was central to his platform. His rants on Twitter, his use of COVID-19 briefings as campaign platforms, his administration's choice to roll back trans-gender rights on the anniversary of one of the deadliest attacks on the LGBTQ community in US history, and his party's choice to hold a rally on the anniversary of the Tulsa Massacre suggested that the performance was a highly orchestrated attack on democracy. Like Richard, Donald Trump was a leader who evoked uncompromising, polarized responses precisely because he both compulsively seeks an audience and in many respects disregards his audience altogether. From the beginning, his candidacy occasioned debate about the nature of leadership and what qualities and skills an individual should possess in order to fill the office of the president. For some, his lack of experience with foreign policy and the law seemed to define his unsuitability for the job, while others looked to his background as a businessman as the model of what American politics needed. Still others saw his lack of experience in politics as precisely the thing that made him an ideal president. Those loyal to Trump's presidency heralded him as a redeemer of American values, in stark contrast to his opponents, many of whom believed that in his four years as president, democracy in the US teetered closer to authoritarianism than anyone ever thought possible. Trump's response to dissension of any kind was not unlike Richard's impulse to galvanize the authority of his office at the expense of his people. Surrounding himself with loyalists, often friends and family, Trump was more concerned with his own 
ratings than with the work of a president. For the four years of his presidency, the US felt the effects of what one writer called "the death of expertise."15

Just as Richard's performativity creates a kind of gravity that compels others to perform a role within the political play he directs, so too has Trump's performance of leadership turned the US into a theater-at-large with the American public seemingly trapped within a culture of political performance. The quick politicization of the COVID-19 health crisis in the US offers just one case study that shows the degree to which unabashed and unfettered performativity can not only be used to undermine social relations within a society, but to create the conditions in which civic responsibility collapses into performance. The nature and magnitude of the danger of Trump's disavowal of experts came to the forefront in February 2020 when the first COVID-19 cases were identified in the US. With Trump having gutted the pandemic response team, broken ties with the World Health Organization, denied the recommendations of the Centers for Disease Control and Prevention, frequently positioned himself at odds with even the members of his own task force, publicly disavowed mask wearing, indicated his preference for less testing rather than more, and advocated the use of household chemicals and unapproved drugs to combat the virus, the death of expertise was followed swiftly by death itself.

What Richard II provides, then, is a place to interpret and reflect upon the importance of individual judgment and resistance as an alternative form of leadership in the face of political institutions that have been supplanted by pageantry without principle and an authentic individualism that has collapsed into role playing. The question remains how a citizen can break free from the performativity of the highest-ranking government official to affect reform. In the essay that follows, I trace the creation and the perpetuation of performative culture in Richard II. In particular, I argue that Richard's performativity has three major consequences: it indicates the weakness of his own political leadership, it threatens to undermine the legitimacy of Bolingbroke's resistance to weak leadership, and it renders the judgment of the audience uncertain. Richard II reveals the dangers of weak leadership to society at many different levels, a truth that is as cogent in late sixteenth-century England as it is in twenty-first-century America.

\section{RICHARD, BOLINGBROKE, AND THE CULTURE OF POLITICAL PERFORMANCE}

Although Shakespeare's Richard is hardly a fully realized historical figure, the performative aspects in Richard's character - and the performativity he inspires in his subjects-were not far from the historical mark. Shakespeare's play ignores the historical circumstances surrounding much of Richard's reign leading up to his deposition, including the threats to his sovereignty that 
abounded for most of his life. ${ }^{16}$ The clearest manifestation of these threats was the Peasants Revolt of 1381, which served as a wake-up call to the aristocracy and the monarch about the precariousness of their position. As the social structure of English medieval society was transitioning away from the feudal system to something as yet undefined, the lower classes were "aggravated by the administrative incompetence and selfishness superadded by the ruling classes to their normal display of luxury and cruelty, by the unpopularity of a government which did not work in any sense of the word, was corruptly administered, supported by heavy taxation and inclined to shift the burden of taxation, as far as it dared, from the rich on to the poor." ${ }^{" 17}$ It is in the context of this popular outcry against corruption, ineptitude, and extravagance that Richard emerged as a ruler committed not to reform but to reestablishing his sovereignty by exalting ceremony and creating a language of power for his rule. ${ }^{18} \mathrm{He}$ not only re-envisioned the monarch's role as a political performer, but also sought to enhance his subjects' "performance of obedience." ${ }^{19}$ Despite his youth and inexperience, he restored order to England in the wake of the Peasants Revolt.

Nevertheless, Richard's reign is characterized by a distrust and factionalism that he attempted to overcome with ritual and prerogative. Richard ascended the throne as a ten-year-old boy in 1377 after the death of his father Edward III. By the late 1380s, he declared the autonomy of his rule separate from his ambitious uncles who had carefully watched the young monarch, other political factions at the court, and Parliament, which sought to create a counsel to oversee his actions and impinge upon his prerogative. Seeking to secure his authority against Parliament, for the first time in English history a monarch pitted his judges against Parliament, asking them to make a political judgment about whether or not Parliament had overstepped its bounds. ${ }^{20}$ Perhaps not surprisingly, the judges spoke in Richard's favor. The king's prerogative may have suggested to him that he was above the law, but the English people and aristocracy - and, in fact, English law - took a different view. By the late 1390s, Richard had gained a reputation as a king who frequently used his prerogative for his own benefit rather than the benefit of his people. ${ }^{21}$ It was only at the end of his reign leading up to his deposition in 1399-which is when Shakespeare's play begins - that Richard started lashing out at his opponents in order to consolidate his power even further.

This historical background is useful for understanding Shakespeare's play, because it suggests a rationale for a monarch who would be highly invested in both his own political performance and that of his subjects. The historic Richard II put great stock in the performance of power as a means of maintaining his sovereignty. Richard's use of language for political performance was heightened by Shakespeare as he chose to focus on the events leading up to Richard's abdication. By focusing almost exclusively on the moment 
when the king loses his power, Shakespeare draws back the curtain on the cracks in Richard's political edifice. ${ }^{22}$ In Shakespeare's play, Richard's faults are many - he is naïve, unskilled, egotistical, and given to poetics more than politics; he violates the rights of the aristocracy; he taxes people unfairly for his own interests; and, in what is perhaps the biggest of his political sins, he imprudently surrounds himself with "caterpillars" who offer him bad counsel. Despite all these flaws, he is not simply a king who "renteth right and law asunder." ${ }^{23}$ The play cannot be called a morality play or even a tragedy, wherein a great ruler is brought low by his individual moral shortcomings. Instead, the play depicts two potentially valid forms of leadership, those of Richard and Bolingbroke.

In its staging of competing performances and performance styles, Richard II consistently refuses to adjudicate the Richard-Bolingbroke binary that structures this work. For example, the prophecy of the Bishop of Carlisle, a loyal member of Richard's inner circle, asks the audience to consider the actions of the play not in and of themselves, but within the context of a larger view of history. Thus, though perhaps the immediate political situation validates Bolingbroke's claim to power, the words of Carlisle to Bolingbroke and his uncle, the Duke of York, foreshadow a future for England that will be characterized by conflict as a consequence of this claim:

CARLISLE If you crown him, let me prophesy

The blood of English shall manure the ground,

And future ages groan for this foul act.

Peace shall go sleep with Turks and infidels,

And in this seat of peace tumultuous wars

Shall kin with kin and kind with kind confound.

Disorder, horror, fear, and mutiny

Shall here inhabit, and this land be called

The field of Golgotha and dead men's skulls. (4.1.127-35)

Carlisle's judgment represents the play's overarching mood of dread, essentially damning England to a future of unrest and bloodshed. The crowning of Bolingbroke not only makes England vulnerable to civil war, but symbolically transforms England into a Golgotha, the place where Christ was crucified. Richard, the divinely anointed king who serves as God's deputy on earth, is likened to the martyred Christ, while Bolingbroke's actions are demonized.

Despite the testimonial of this tempting rendering of English history, however, the play also takes seriously the legitimacy of Bolingbroke's response to a failed monarch. ${ }^{24}$ Shakespeare provides the audience with an abundance of judgments about these two men and the legitimacy of their claims to the throne, but none of these pronouncements effectively alleviates the play's atmosphere of unease. ${ }^{25}$ The evidence of the play itself suggests 
that the audience should reserve judgment, or at least employ a different set of criteria than any of the overt ideological viewpoints presented in the play itself.

The first scene of Richard II sets the stage for the performativity of both the monarch and his court, as both Richard and Bolingbroke are rendered morally suspect characters. Because the scene that Shakespeare constructs effectively neutralizes any moral argument that could be made for or against either character, it puts the audience in the seat of judgment, as they try to untangle and assess the strengths and weaknesses of either character based on their leadership skills rather than on the strength of their individual ethics or political ideologies. Indeed, though it may seem at first that an audience is called on to weigh against each other these two leaders and their causes, in the end we see not opposition but two political choices that seem more similar than different.

The play opens with the audience seemingly sharing Richard's point of view, having to make a judgment call between two political factions. When the two aristocrats Bolingbroke and Mowbray enter, heatedly accusing each other of treason, Richard notes "yet one but flatters us" (1.1.25). Both Mowbray and Bolingbroke are hiding secrets in this scene, though on the surface they appear to be performing the obedience and loyalty due to a monarch. Mowbray is covering up the fact that Richard ordered him to murder his uncle, Thomas of Woodstock, an act that precedes the action of the play. Although Mowbray worries about Richard's partiality to Bolingbroke given that they are cousins, Richard appears to assume the part of an impartial judge in the contest, noting that both Mowbray and Bolingbroke are equal subjects under him (1.1.110-23). Setting aside the issues that both men bring to Richard's court, Richard contrives a duel to resolve the conflict, though the king ultimately discards that pretense and uses his prerogative to banish both Bolingbroke and Mowbray from England. But if the audience does not have enough information upon which to judge Bolingbroke, it also does not have the information with which to evaluate Richard. In a notoriously veiled line, Mowbray seems to allude to the possibility that Richard ordered the murder of Thomas of Woodstock, but the play does not confirm Richard's guilt until the next scene. The fact that some of Shakespeare's audience would have known the story of Richard's murder of Woodstock seems to make it all the more conspicuous that Shakespeare leaves out that information from this scene. ${ }^{26}$

The opening scene, then, does not establish Bolingbroke as the morally superior of the two men, but it does establish him as someone capable of producing a political performance. Indeed, as one scholar has pointed out, Bolingbroke's name may be a pun on "bulling," which meant to deceive. ${ }^{27}$ Scholarship is decidedly split on how to interpret the character of Bolingbroke and the degree to which he represents a Machiavellian model of leadership that is ushering out an older version of leadership premised on sacred kingship. ${ }^{28}$ His character embodies a version of leadership which is much more 
uncertain and difficult to interpret. Whereas Shakespeare gives Richard several moments of self-reflection throughout the play, he offers no equivalent insight into Bolingbroke's interiority. ${ }^{29}$ One crucial detail that seems to be intentionally left in doubt throughout the play is Bolingbroke's motivation. The opening lines of the play introduce the problem of interpreting political performance when even the man who is closest to Bolingbroke, his father, John of Gaunt, can offer little insight into his son's thoughts. When Richard asks Gaunt in a private conversation whether his son's suit is motivated by "ancient malice or worthily, as a good subject should" (1.1.9-10), Gaunt says that he believes his son to be alerting the king to "some apparent danger," though he admits that this is "as near as I could sift him on that argument" (1.1.12-13). Gaunt's hardly confident response registers an uncertainty about Bolingbroke's motives that recurs throughout the play. It also makes it seem likely that the two aristocrats are involved in a courtly dumbshow, rather than an earnest challenge, to demonstrate their loyalty as subjects to the king. In other words, Act 1, Scene 1 is less about political action based on conviction than the performance of conviction.

While Bolingbroke's motivations for accusing Mowbray are obscure, Mowbray himself argues for the purity of his intent in serving Richard, and indeed by the end of the play his claim that Bolingbroke's professed loyalty to the king is just a ruse will be proven to be correct. Questions about Bolingbroke's intentions dominate the rest of the play, leading the audience to wonder whether we should view him as the protagonist we might expect him to play to Richard's antagonist or not. All Shakespeare allows us to know for certain after this scene is that Richard's court is one in which professions of loyalty are nearly impossible to differentiate from loyalty itself. Richard's handling of Mowbray and Bolingbroke within the context of his courtly theater shows him managing their entrances and their exits in an attempt to cover up his own unscrupulous leadership.

Despite the play's title, Bolingbroke is the more dynamic character within the play. Whatever Bolingbroke's failures as a leader, and however dark the shadow of usurpation, the restoration of succession in the figure of Bolingbroke's son as Henry V seems to outweigh the moral ambiguity of Bolingbroke's claim to the crown. Yet when we leave the long-term consequences of Richard's abdication aside, we are left with one of the central questions of the play. Bolingbroke is either a reformer or he is a political performer, and the play seems to suggest that he cannot legitimately be both. Richard's favoritism, financial indulgences, and murderous tendencies make reform necessary, yet the performativity that shrouds all actions within the court threatens to render Bolingbroke's actions as mere performance rather than political act. To unravel what this play has to say about leadership and performativity, we 
have to assess more accurately Bolingbroke's character as a leader using the information - and in some cases the lack of information - that we have.

Shakespeare provides the audience with two competing axes against which to judge Bolingbroke's leadership. On the one hand, Bolingbroke is repeatedly positioned as the foil to Richard and as his rival for the throne. In this sense, the play is inscribed with a rhetoric of opposition such as that reflected in Carlisle's highly allegorical speech. However, the evidence of the play points to the similarities rather than the differences between these two men, suggesting that this opposition is a false binary. In place of this binary, the play presents a range of responses and interpretations, including those of Bolingbroke's father, John of Gaunt; Bolingbroke's uncle, the Duke of York; and Bolingbroke himself. These responses range from the religious to the secular, and from passive conformity to active reform.

The first of these views is offered early in the play by Bolingbroke's father, John of Gaunt, in the second scene of the play. In a quaint and private encounter in which Gaunt is speaking to the Duchess of Gloucester, the widow of his murdered brother, he confirms what the first scene did not: Richard's guilt in the murder of his brother, Thomas of Woodstock. In response to her plea for revenge, Gaunt recites the most conservative version of orthodox doctrine on the subject's duty to a sovereign:

GAUNT God's is the quarrel; for God's substitute,

His deputy anointed in his sight,

Hath caused his death; the which if wrongfully,

Let heaven revenge, for I may never lift

An angry arm against his minister. (1.2.37-41)

Affirming the values of sacred kingship, Gaunt defers judgment to God, because only God is the superior to an anointed king. Nevertheless, the widow makes clear that Gaunt's response is dissatisfying at best. It also may well seem dissatisfying to the audience, as "Gaunt's orthodoxy is a way of rationalizing political impotence." ${ }^{30}$ Similar to the political views he expresses in his deathbed speech in which he nostalgically compares England to an "other Eden, demi-paradise" (2.1.42), Gaunt's ideas seem entirely utopian and out of touch with the political realities of the moment. ${ }^{31}$ Although Gaunt is characterized as a wise and honest counsellor who speaks hard political truths, he dies early in the play, a historical fact that would seem to corroborate the sense that he no longer belongs in the political world Shakespeare constructs. ${ }^{32}$ Hence, Gaunt's version of citizenship seems unlikely to reform the political problems that ail England.

Gaunt's last remaining brother, the Duke of York, offers a similarly conservative view of reform, but his view is rooted more in a secular ethic than 
Gaunt's argument that the English should patiently suffer any and all abuse at the hand of God's anointed king. When Richard decisively and imprudently seizes Gaunt's lands just moments after the aristocrat's death is announced in order to fund his Irish wars, York immediately replaces Gaunt as the play's figure of an ideal counsellor, keen to tell Richard what he does not want to hear. He is the first to diagnose Richard's violations of Bolingbroke's right to his inheritance and their consequences for the king's hold on the throne:

YORK Take Hereford's rights away, and take from Time

His charters and his customary rights

Let not tomorrow then ensue today;

Be not thyself, for how art thou a king

But by fair sequence and succession? (2.1.196-200)

Like Gaunt, York is a kind of idealist, but rather than centering his belief on England's Edenic past or sacred kingship, he grounds his arguments in English law. But while Gaunt's rhetoric reflects the certainty of his beliefs, many of York's speeches end with questions. York notes that if the king ignores the right of inheritance, he not only defies the basic tenets of English common law, but he also invalidates the foundation of his own political power. This realization leads him to the question of whether or not it is ever appropriate for a subject to rebel against a monarch who disregards law. He begins his critique of Richard's seizure of Gaunt's lands with a question that looms over the entire play: "How long shall I be patient? Ah, how long / Shall tender duty make me suffer wrong?" (2.1.164-5). While Gaunt had argued for the patient suffering of a dutiful subject, York's rhetorical questioning suggests that there must be an end to patience. At some point, then, it must be valid for a subject to judge the sovereign and to act upon that judgment. Richard's actions have gone so beyond the pale of English law that he has pushed York's "tender patience to those thoughts / Which honour and allegiance cannot think" (2.1.208-9).

York comes to the very brink of becoming a reformer, only to quickly retreat from such action. Once confronted with the reality of Bolingbroke's rebellion, he decides there must be a limit to men's actions in the face of injustice, and that patience and suffering rather than reformation may be the best stance for a dutiful subject to take. In Act 2, Scene 3, York emerges as a sharp critic of Bolingbroke's treason. Though usually a man of few words and direct language, the high rhetoric Bolingbroke employs in his response to York confirms what we have already suspected: that he too is quite capable of playing political games. When he bows before his uncle, York replies to his nephew, "Show me thy humble heart, and not thy knee, / Whose duty is deceivable and false" (2.3.83-4). When Bolingbroke appeals to his "gracious uncle," York immediately identifies and cuts off his nephew's flattery: "Tut, 
tut, grace me no grace, nor uncle me no uncle. / I am no traitor's uncle, and that word 'grace' / In an ungracious mouth is but profane" (2.3.86-8). Far from viewing Bolingbroke as a reformer, York sees him as a "traitor" lacking grace, for having violated decorum and law by returning to England from exile and also because he is acting without the grace or favor of God. Offering a quick assessment of Bolingbroke's "gross rebellion and detested treason" that pulls no punches, he condemns Bolingbroke's return to England, just as he had censured the king for stealing Bolingbroke's lands. Because York has been left with insufficient powers to arrest Bolingbroke, he says that he has no choice but to remain "neuter," that is, an impartial judge (2.3.158), which may be one model of response but is not a model of reform.

With Gaunt and York as two failed models of response to Richard, we arrive at the possibility that Bolingbroke's resistance may be read as an active and justifiable model of reform. The scene ends with Bolingbroke arguing for himself as a corrective to "the caterpillars of the commonwealth, / Which I have sworn to weed and pluck away" (2.3.165-6), yet there is little to suggest that Bolingbroke is the reformer he claims to be. He does rid England of some of Richard's more expendable "caterpillars," but it is hard to see what this action has to do with his rightfully reclaiming the land Richard has taken from him. In addition to the inscrutability of Bolingbroke's political motivations and the illegality of his actions, the odd compression of Act 2, Scene 1 in which Bolingbroke's father, John of Gaunt, dies, Richard seizes his land, and Bolingbroke returns further renders Bolingbroke's motivations suspect. The compression of this timeline underscores the ambiguities surrounding Bolingbroke's motivations for his early return. And so, as Richard has broken the law of English custom, Bolingbroke responds by breaking the law as well. As the play continues, the parallels between Richard and Bolingbroke become even stronger. In Act 3, Scene 3, Bolingbroke shows himself to be more than willing to create the conditions for civil war, though he describes his position as "yielding water" that will give way to Richard's raging fire (3.3.57-9). Yet the potential for violence Bolingbroke evokes here when he threatens to "lay the summer's dust with showers of blood / Rained from the wounds of slaughtered Englishmen" (3.3.40-1) seems to echo York's earlier condemnation of Richard's flouting of English law. This at once makes Bolingbroke seem like a reformer while suggesting a parallel between his actions and those of Richard at the same time.

If Bolingbroke's lawlessness and the threat of civil war he poses were not enough evidence to confirm his similarities with Richard in a way that defies the ostensible rhetoric of opposition in the play, by the end of Act 4, when Richard abdicates, we are once again confronted with the problem of interpretation. The way in which Shakespeare blurs the line between treating Richard's downfall as a deposition caused by the threat of rebellion and an 
abdication caused by a monarch with limited skills as a leader is important. Richard himself is the one who first mentions deposition, though he seems to voluntarily give up the crown to Bolingbroke. The difference has a significant impact on how we interpret Bolingbroke, for not only does an abdication suggest Richard's lack of leadership, but it also suggests Bolingbroke's insofar as he becomes a kind of accidental king.

In this scene it becomes clear why this play is really Richard's play and not Bolingbroke's. Although Bolingbroke calls Richard to a public deposition scene, Richard largely choreographs his own deposition. Throughout the scene Bolingbroke is confined to single line answers, while Richard's speeches are capacious, full of pathos, and highly rhetorical. When he gives the crown and scepter to Bolingbroke, Richard commands, "Now mark me how I will undo myself":

RICHARD With mine own tears I wash away my balm, With mine own hands I give away my crown, With mine own tongue deny my sacred state, With mine own breath release all duteous oaths.

All pomp and majesty I do forswear. (4.1.192, 197-201)

Ironically, Richard's renunciation of his own divine kingship only reaffirms it. As a divinely anointed king, he has no superiors on earth: the only person who can dethrone him is he himself. Richard further highlights his orchestration of the scene by condemning his deposers as "Pilates" who will not be able to "wash away your sin" $(4.1 .230,232)$. Bolingbroke's ally, the Earl of Northumberland, attempts to step in and establish order by demanding that Richard read a list of grievances that provide the rationale for his deposition. After Northumberland's fourth attempt to get Richard to take the list, Bolingbroke tells him to give up his suit. The scene concludes with Bolingbroke supplying two of Richard's final requests, a mirror in which to view his ruined self and permission to leave Bolingbroke's presence forever. Although Richard is sent to the Tower, Richard's last words in a scene that he has already dominated once again cast Bolingbroke and his allies in a negative light as he calls them "conveyors," a derogatory term indicating thievery.

The way in which Richard's deposition scene unfolds makes it seem to be a voluntary, but unjust, abdication of power. Richard's rhetorical command and performative power is unmistakable for the entire time he is on stage. The audience does witness a transfer of power, but it does not seem to be one occasioned by Bolingbroke's desire for reform; rather, it is occasioned by Richard's own weakness as a leader. This scene is easily the climax of the play, but even as Richard's performance of kingship is at its height, Bolingbroke's motivations are unclear, and they remain so in the final act. During the last moments 
of the play, Richard's executioner, Exton, enters with the coffin containing Richard II's murdered body. ${ }^{33}$ The new king, Henry IV, does not thank Exton for carrying out the murder, though Exton insists, "From your own mouth, my lord, did I this deed" (5.6.37). The audience never sees Henry give this order; instead, we only hear about the coded language Henry uses when he is quoted by Exton in an early scene as saying, "Have I no friend will rid me of this living fear?" (5.4.4). The indirect way in which Shakespeare gives the audience information about Bolingbroke once again calls to our attention the skill with which Bolingbroke uses political performance. Nevertheless, the play "closes, as it had opened, on a king whose hands are stained with royal blood," and with another order for banishment, this time Exton's, that will likely cause as many problems as it solves. ${ }^{34}$ Even Henry acknowledges his own guilt as he swears to "make a voyage to the Holy Land / To wash this blood off from my guilty hand" (5.649-50). Although his actions as a reformer cannot be read outside of Richard's display of anointed kingship, with the death of Richard, Henry is free to enjoin his own political performance or to leave political performance aside entirely.

\section{NEGOTIATING POLITICAL PERFORMANCE}

Richard II is such a painfully powerful and prescient play in the twenty-first century because, despite the historical and political differences, it speaks to important questions in our own time about leadership, the relationship between political performance and political action, and the duty of an individual confronted by inadequate leadership to work within or to rebel against a dysfunctional political system. Shakespeare's Richard is by all accounts a foolish and unskillful king: he ignores the law, abuses his people with taxation, is counselled by an echo chamber of his own creation, and rules by prerogative. When York advises Richard — for his own good — to forgo taking Gaunt's lands just moments after Gaunt has died, Richard's response is uncharacteristically short and direct: "Think what you will, we seize into our hands / His plate, his goods, his money, and his lands" (2.1.210-11). The rhyming couplet only serves to underscore Richard's flippancy: he does not even care enough about his audience to try to cover up his violation of English law. From the point of view of many Americans - the popular vote of the 2016 election would suggest that it was the majority of Americans - never before were American citizens faced with a ruler like Donald Trump: one who seemed entirely unqualified to be president, who violated, or at least loosely interpreted, constitutional law, who created a panel of advisors made up of like-minded favorites, and who used branches of government against each other for his own political gain. At the very least, Richard II makes us stop and wonder at what qualifies a person for political leadership beyond their ability to act a part. 
Bolingbroke provides us with a model of resistance, even as he shares similarities with the system of misrule he seems to be attempting to reform. He is adept at capitalizing on his popularity with his audience, a fact that leads A. L. Rowse to remark, "Bolingbroke was a politician-he would do quite well in a democracy." ${ }^{35}$ Bolingbroke's tendency to recognize the importance of popular support that spans various classes may be one reason why the play resonates so well with contemporary American politics. Although Richard dominates the scene of his abdication and is often taken to be the active force to Bolingbroke's more passive role, it is Bolingbroke who orchestrates the scene when he calls for Richard to come "that in common view / He may surrender. So shall we proceed / Without suspicion" (4.1.146-8). Richard may be the more obvious actor and a formidable poet, but it is Bolingbroke who is keenly aware of the audience. Richard is not a successful leader precisely because the audience for the play is made aware that they are watching Richard perform a role. By contrast, Bolingbroke is the more accomplished performer. Shakespeare uses his silence strategically and in a way that places great emphasis on the role of the audience-both within the play and within the theater itself to interpret Bolingbroke's actions. This is notable because so often when Shakespeare considers audience in political plays - most notably his Roman plays Julius Caesar, Titus Andronicus, and Coriolanus - the audience is seen as a dangerous and unmanageable crowd. ${ }^{36}$ Nevertheless, Shakespeare does not give a free pass to either Richard or Bolingbroke, and the consequences of Bolingbroke's actions follow him to the last lines of the play. ${ }^{37}$

And so the reason why we cannot simply view Bolingbroke as an answer to the ineptitude of Richard has to do with the way in which Shakespeare forces us to pause throughout the play to consider whether we are able to feel good about our judgment of him as either a rightful king or as a rebellious usurper. Shakespeare arguably does not give the audience enough information with which to judge Bolingbroke, and the information we do have shows Bolingbroke frequently playing into the roles Richard creates for him. The challenge to Mowbray, the duel, and the abdication scene are all performative spaces controlled by Richard in which Bolingbroke plays his part. For most of the play, it is difficult to know exactly what kind of performance he is offering and whether we should see his performance as evidence of his superior skill at politics and his earnest belief in reform or as an indicator that he is not all that different from the man he is replacing on the throne. If, as I have argued, Shakespeare neutralizes moral superiority in the play by creating more similarities than differences between Bolingbroke and Richard, then the play begs the question of what grounds we might use to evaluate Bolingbroke's superiority to Richard. It would seem that the only criteria we have left is to compare Bolingbroke's performativity, which prevents us from knowing what is performance and what is real, to Richard's, in which we always know where 
we stand, dreadful as that may be. If such is the ground that we might apply to our modern political system, we may be left substituting one empty crown for another.

Ultimately, Bolingbroke provides a contemporary audience two different insights on leadership and politics in the twenty-first century. As a rival, counterpoint, and potential reformer, Bolingbroke offers us a critique of the death of expertise. In this light, Bolingbroke, though perhaps morally as culpable as Richard, still offers some skill as a leader that the king lacks. But the second insight is even more troubling - that is, that Bolingbroke is not really much of a reformer at all, and that with a little bit of luck and ambition he falls into the role that Richard's lack of leadership skill creates for him. If we translate these insights into our position as audience and as political subject, we are either, like Bolingbroke, judging Richard's performance and responding to it with reforms to benefit society, or we are judging both Richard and Bolingbroke and have no choice but to take away a highly skeptical view of politics and civic activism in a society in which both have collapsed into performance.

Every four years, during the presidential election, US citizens are faced with the familiar dilemma of differentiating empty campaign promises from the earnest convictions that will provide the motivation to create legislation to strengthen society. The internet age makes it increasingly difficult to see the strings and seams of performance. In many ways, our position is more fraught than that of Shakespeare's audience. Whatever the ambiguities of Shakespeare's play, ultimately history did supply the choice between Richard and Bolingbroke for their audience. However, what we are left with now is a political field full of Bolingbrokes who may or may not be what they claim to be. At the same time, the political subject in the age of Trump veers precariously toward becoming a Bolingbroke. As various social media platforms now make it possible to signal action, the armchair activism of many American citizens allows for the performance of activism rather than the work of activism itself. As Americans negotiate this performative space, failed political leadership threatens to displace proactive reform measures with reactive political performativity.

\section{NOTES}

1. For a discussion of the strength of Richard's claim to the throne compared to other monarchs in Shakespeare's history plays, see Andrew Hadfield, Shakespeare and Renaissance Politics, Arden Shakespeare (London: Thomson Learning, 2004), 40.

2. Charles R. Forker, introduction to King Richard II, by William Shakespeare, Arden Shakespeare, ed. Charles R. Forker (London: Bloomsbury, 2019), 3.

3. As Robin Headlam Wells notes, the play supports neither the "didactic assertion of an 'orthodox' doctrine of absolute obedience to kingly authority, nor, at the other 
extreme, a republican justification of tyrannicide." See Robin Headlam Wells, Shakespeare's Politics (New York: Continuum, 2009), 139.

4. Despite its relevance to the politics of the day, Shakespeare could not have anticipated the play's role in the Essex rebellion. See Forker, introduction to King Richard II, 5. See also Stephen Greenblatt, Tyrant: Shakespeare on Politics (New York: Norton, 2018), 22.

5. Barbara Hodgdon, The End Crowns All: Closure and Contradiction in Shakespeare's History (Princeton, NJ: Princeton University Press, 1991), 134.

6. For a discussion of Charles's identification with Richard, see Ernst H. Kantorowicz, The King's Two Bodies: A Study of Mediaeval Political Theology (Princeton, NJ: Princeton University Press, 1957), 41, and Victoria Kahn, The Future of Illusion (Chicago: University of Chicago Press, 2017), 71.

7. Kristin M. S. Bezio, Staging Power in Tudor and Stuart English History Plays (Burlington, VT: Ashgate, 2015), 117.

8. This and all future quotations from Richard II are from The Norton Shakespeare: Histories, 2nd ed. Edited by Stephen Greenblatt (New York: Norton, 2008).

9. Bezio notes that Bolingbroke's success is due to his "engaging in superior performative negotiation." Bezio, Staging Power in Tudor and Stuart English History Plays, 116.

10. Cf. E. M. W. Tillyard's reading of Richard II in light of the history plays that both precede and follow it. See E. M. W. Tillyard, Shakespeare's History Plays (London: Chatto \& Windus, 1956).

11. Warren Chernaik notes that Elizabethans had a fundamentally different orientation to the past than we do today. See Warren Chernaik, The Cambridge Introduction to Shakespeare's History Plays (Cambridge: Cambridge University Press, 2007).

12. Doyeeta Majumder, Tyranny and Usurpation: The New Prince and Lawmaking Violence in Early Modern Drama (Liverpool: Liverpool University Press, 2019), 197.

13. Wells, Shakespeare's Politics, 131.

14. Louise Cowan, "God Will Save the King: Shakespeare's Richard II," in Shakespeare as Political Thinker, ed. John Alvis and Thomas G. West (Durham, NC: Carolina Academic Press, 1981), 69.

15. Tom Nichols, The Death of Expertise (New York: Oxford University Press), 2017.

16. For a complete discussion of Shakespeare's sources for the play, see Geoffrey Bullough, Narrative and Dramatic Sources of Shakespeare (London: Routledge \& Kegan Paul, 1960).

17. Anthony Steel, Richard II (Cambridge: Cambridge University Press, 1962), 73-4.

18. On the importance of finding a language of power, see Lynn Staley, Languages of Power in the Age of Richard II (University Park: Pennsylvania State University Press), 2005.

19. Nigel Saul, The Three Richards (New York: Palgrave Macmillan, 2005), 60.

20. Saul, The Three Richards, 57.

21. On the way in which his use of prerogative positioned Richard both above and subject to the law, see Donna B. Hamilton, "The State of Law in Richard II," Shakespeare Quarterly 34, no. 1 (1983): 14.

22. On Shakespeare's "unsystematic" use of history, see Jeremy Lopez, "Eating Richard II," Shakespeare Studies 36 (2008): 207.

23. L. B. Campbell, ed., The Mirror for Magistrates (New York: Barnes \& Noble, Inc, 1960), 111. 
24. On the play's emphasis on failure, see Robyn Bolam, "Richard II: Shakespeare and the Languages of the Stage," in The Cambridge Companion to Shakespeare's History Plays, ed. Michael Hattaway (Cambridge: Cambridge University Press, 2002), 153.

25. Comparing Richard II to the unflinching pessimism of Marlowe's Edward III, A. L. Rowse argues that Shakespeare's play offers the audience "every sort of alleviation" (236). Nevertheless, Shakespeare's play is riddled with an uncertainty that hinges upon the contest between Richard and Bolingbroke. See A. L. Rowse, William Shakespeare: A Biography (New York: Harper \& Row, 1963).

26. Many scholars have remarked on Shakespeare's choice to leave Richard's culpability in doubt in the first scene. See Nicholas Grene, Shakespeare's Serial History Plays (New York: Cambridge University Press, 2002), 77.

27. Bolam, "Richard II: Shakespeare and the Language of the Stage," 142.

28. Some scholars see Bolingbroke as an "accomplished Machiavel"; see for example, Leon Harold Craig, The Philosopher's English King: Shakespeare's Henriad as Political Philosophy (Rochester, NY: University of Rochester Press, 2015), 29-30. Barbara Hodgdon calls him the "Machiavellian new man" (The End Crowns All, 130). A. D. Nuttall, on the other hand, notes that Shakespeare could have made Bolingbroke a consummate Machiavel, but chose not to. See A. D. Nuttall, Shakespeare the Thinker (New Haven, CT: Yale University Press, 2007), 137.

29. Craig, The Philosopher's English King, 68.

30. See C. G. Thayer, Shakespearean Politics: Government and Misgovernment in the Great Histories (Athens: Ohio University Press, 1983), 2.

31. Nicholas Grene distinguishes the "mystical form of nostalgia" (172) that characterizes Richard II from the Henry IV plays. See Grene, Shakespeare's Serial History Plays.

32. The historic Gaunt was much more ambitious than Shakespeare's version. See Peter Saccio, Shakespeare's English Kings: History, Chronicle, and Drama (Oxford: Oxford University Press, 1977), 20.

33. On the symbolic importance of the body of Richard II, see Imke Lichterfeld, "'Thou livest and breathest, yet art thou slain in him': The Absence of Power in Richard II," Comparative Drama 50, no. 2-3 (Summer \& Fall 2016): 2-3.

34. Saccio, Shakespeare's English Kings, 35.

35. Rowse, William Shakespeare, 239.

36. Bezio argues that Bolingbroke's popularity and military support act as a "caution to potential tyrants about the potential threat posed by the populace through rebellion." See Bezio, Staging Power in Tudor and Stuart English History Plays, 117.

37. Rowse, William Shakespeare, 237.

\section{REFERENCES}

Bezio, Kristin M. S. Staging Power in Tudor and Stuart English History Plays. Burlington, VT: Ashgate, 2015.

Bolam, Robyn. "Richard II: Shakespeare and the Languages of the Stage." In The Cambridge Companion to Shakespeare's History Plays, edited by Michael Hattaway, 141-57. Cambridge: Cambridge University Press, 2002.

Bullough, Geoffrey. Narrative and Dramatic Sources of Shakespeare. London: Routledge \& Kegan Paul, 1960. 
Campbell, L. B., editor. The Mirror for Magistrates. New York: Barnes \& Noble, Inc, 1960.

Chernaik, Warren. The Cambridge Introduction to Shakespeare's History Plays. Cambridge: Cambridge University Press, 2007.

Cowan, Louise. "God Will Save the King: Shakespeare's Richard II.” In Shakespeare as Political Thinker, edited by John Alvis and Thomas G. West, 63-81. Durham, NC: Carolina Academic Press, 1981.

Craig, Leon Harold. The Philosopher's English King: Shakespeare's Henriad as Political Philosophy. Rochester, NY: University of Rochester Press, 2015.

Forker, Charles R. Introduction to King Richard II, by William Shakespeare, Arden Shakespeare, 1-169. Edited by Charles R. Forker. London: Bloomsbury, 2019.

Greenblatt, Stephen. Tyrant: Shakespeare on Politics. New York: Norton, 2018.

Grene, Nicholas. Shakespeare's Serial History Plays. New York: Cambridge University Press, 2002.

Hadfield, Andrew. Shakespeare and Renaissance Politics. Arden Shakespeare. London: Thomson Learning, 2004.

Hamilton, Donna B. "The State of Law in Richard II." Shakespeare Quarterly 34, no. 1 (1983): 5-17.

Hodgdon, Barbara. The End Crowns All: Closure and Contradiction in Shakespeare's History. Princeton, NJ: Princeton University Press, 1991.

Kahn, Victoria. The Future of Illusion. Chicago: University of Chicago Press, 2017.

Kantorowicz, Ernst H. The King's Two Bodies: A Study of Mediaeval Political Theology. Princeton, NJ: Princeton University Press, 1957.

Lichterfeld, Imke. “"Thou livest and breathest, yet art thou slain in him': The Absence of Power in Richard II." Comparative Drama 50, no. 2-3 (Summer \& Fall 2016): 195-207.

Lopez, Jeremy. "Eating Richard II." Shakespeare Studies 36 (2008): 207-8.

Majumder, Doyeeta. Tyranny and Usurpation: The New Prince and Lawmaking Violence in Early Modern Drama. Liverpool: Liverpool University Press, 2019.

Nichols, Tom. The Death of Expertise, New York: Oxford University Press, 2017.

Nuttall, A. D. Shakespeare the Thinker. New Haven, CT: Yale University Press, 2007.

Rowse, A. L. William Shakespeare: A Biography. New York: Harper \& Row, 1963.

Saccio, Peter. Shakespeare's English Kings: History, Chronicle, and Drama. Oxford: Oxford University Press, 1977.

Saul, Nigel. The Three Richards. New York: Palgrave Macmillan, 2005.

Shakespeare, William. Richard II. The Norton Shakespeare: Histories, 2nd ed. Edited by Stephen Greenblatt. New York: Norton, 2008.

Staley, Lynn. Languages of Power in the Age of Richard II. University Park: Pennsylvania State University Press, 2005.

Steel, Anthony. Richard II. Cambridge: Cambridge University Press, 1962.

Thayer, C. G. Shakespearean Politics: Government and Misgovernment in the Great Histories. Athens: Ohio University Press, 1983.

Tillyard, E. M. W. Shakespeare's History Plays. London: Chatto \& Windus, 1956.

Wells, Robin Headlam. Shakespeare's Politics. New York: Continuum, 2009. 